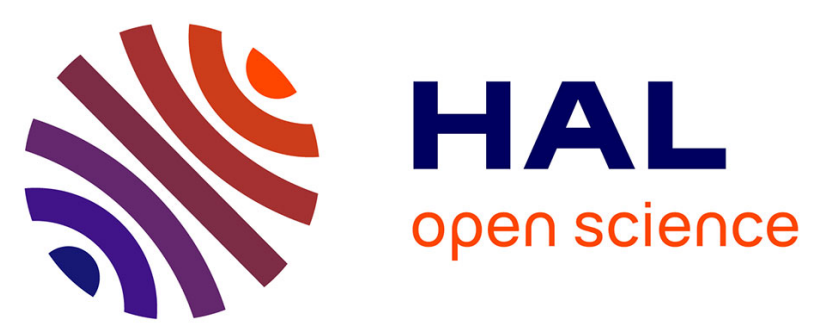

\title{
Abiotic stressors and stress responses: What commonalities appear between species across biological organization levels?
}

Cécile Sulmon, Joan van Baaren, Francisco Cabello-Hurtado, Gwenola Gouesbet, Françoise Hennion, Cendrine Mony, D Renault, Myriam Bormans, Abdelhak El Amrani, Claudia Wiegand, et al.

\section{To cite this version:}

Cécile Sulmon, Joan van Baaren, Francisco Cabello-Hurtado, Gwenola Gouesbet, Françoise Hennion, et al.. Abiotic stressors and stress responses: What commonalities appear between species across biological organization levels?. Environmental Pollution, 2015, 202, pp.66-77. 10.1016/j.envpol.2015.03.013 . hal-01132697

HAL Id: hal-01132697

https://hal-univ-rennes1.archives-ouvertes.fr/hal-01132697

Submitted on 25 Mar 2015

HAL is a multi-disciplinary open access archive for the deposit and dissemination of scientific research documents, whether they are published or not. The documents may come from teaching and research institutions in France or abroad, or from public or private research centers.
L'archive ouverte pluridisciplinaire HAL, est destinée au dépôt et à la diffusion de documents scientifiques de niveau recherche, publiés ou non, émanant des établissements d'enseignement et de recherche français ou étrangers, des laboratoires publics ou privés. 
Abiotic stressors and stress responses: what commonalities appear between species across biological organization levels?

Cécile Sulmon ${ }^{1}$, Joan van Baaren ${ }^{1}$, Francisco Cabello-Hurtado ${ }^{1}$, Gwenola Gouesbet ${ }^{1}$, Françoise Hennion ${ }^{1}$, Cendrine Mony ${ }^{1}$, David Renault ${ }^{1}$, Myriam Bormans ${ }^{1}$, Abdelhak El Amrani $^{1}$, Claudia Wiegand ${ }^{1,2}$ and Claudia Gérard ${ }^{1 *}$

*These authors contributed equally to this study

${ }^{1}$ UMR CNRS 6553 ECOBIO, Université de Rennes 1, 263 Avenue du Général Leclerc, 35042 Rennes cedex, France

${ }^{2}$ Biologisk Institut, Syddansk Universitet, Campusvej 55, 5230 Odense M, Danmark

Corresponding authors: C. Gérard and C. Sulmon

E-mail: claudia.gerard@univ-rennes1.fr; $\underline{\text { cecile.sulmon-maisonneuve@univ-rennes1.fr }}$ Tel. 33223235123; Fax 33223235026 


\begin{abstract}
Organisms are regularly subjected to abiotic stressors related to increasing anthropogenic activities, including chemicals and climatic changes that induce major stresses. Based on various key taxa involved in ecosystem functioning (photosynthetic microorganisms, plants, invertebrates), we review how organisms respond and adapt to chemical- and temperatureinduced stresses from molecular to population level. Using field-realistic studies, our integrative analysis aims to compare i) how molecular and physiological mechanisms related to protection, repair and energy allocation can impact life history traits of stressed organisms, and ii) to what extent trait responses influence individual and population responses. Common response mechanisms are evident at molecular and cellular scales but become rather difficult to define at higher levels due to evolutionary distance and environmental complexity. We provide new insights into the understanding of the impact of molecular and cellular responses on individual and population dynamics and assess the potential related effects on communities and ecosystem functioning.
\end{abstract}

\title{
Capsule
}

The commonality of stress responses to chemical and thermal stressors among taxa is evident at the molecular and cellular scales but remains unclear at higher levels of organization.

\section{Highlights}

Responses to chemical and thermal stressors are reviewed across organization levels. Common responses between taxa are evident at the molecular and cellular scales. At individual level, energy allocation connects species-specific stress responses. Commonality decreases at higher levels due to increasing environmental complexity. Key words: Chemical and thermal stressors, common stress responses, organization level, photosynthetic organisms, invertebrates. 


\section{Introduction}

Within their habitats, organisms are regularly subjected to stressors commonly defined as significant environmental deviations from optimal life conditions that decrease their fitness (Larcher, 2003; Roelofs et al., 2008). Organisms may suffer physiological effects affecting homeostasis and changing cellular metabolism and activity, which is termed as stress (Lichtenthaler, 1996; Steinberg, 2012). Stress can lead to severe damage or to specific responses that prevent or repair damage, depending on the degree of stress and the sensitivity of organisms (sensitive, tolerant, or resistant) (Lichtenthaler, 1996; Steinberg, 2012). Tolerance and resistance correspond to organisms' abilities to cope with stress with reduced or even no adverse effects, using mechanisms of stress avoidance, protection and defense (Calow, 1999). From an ecological perspective, the degree of stress sensitivity determines the edge of the ecological niche for species by exerting selective forces on the performance of life history traits (Roelofs et al., 2008). Because these traits can affect population dynamics and hence community composition, stressors (and related stresses) can result in community-scale effects and may ultimately drive species coexistence and community structures (Pierce et al., 2005; Steinberg, 2012; Moe et al., 2013). Consequently, the risk assessment of stressors must broaden its ecological base (Van Straalen, 2003; Beketov and Liess, 2012).

One challenge facing ecologists is understanding the mechanisms and extent of stress that influence biodiversity, community structure, and ecosystem functioning. The impacts of stressors are generally investigated using two, often disconnected, ways. The first way consists of analyzing molecular and trait responses to stressors of individuals of a given species, using "omics” and ecophysiological approaches. Such studies are mainly conducted under controlled conditions in order to link physiological and morphological stress outcomes to molecular mechanisms and cellular targets. High stress levels are often used to clarify mechanisms; however, studies using more environmentally realistic levels of stressors are 
increasing. The second way investigates the effects of stressors on populations and communities using mesocosms and field experiments, involving relevant stress levels and complex additional abiotic and biotic interactions. The majority of stress studies focus on certain responses of either one (model) species or a few closely related taxa. The disjunction of these two approaches results in incomplete and disconnected knowledge concerning how stress affects the diversity of taxa at the different levels of biological organization, and does not allow ecologists to develop an integrative view of the ecological and evolutionary consequences of stress.

Environmental stressors are widely diverse: they can be abiotic and/or biotic, and often vary in exposure time (acute to chronic) and intensity. Moreover, organisms must often cope simultaneously with several related or unrelated stressors that may significantly influence both the total level of stress sensed by the organisms (multi-stress conditions) and their biological responses. Given the increasing human-related alterations of ecosystems, this review focuses on chemical and thermal stressors, which represent important abiotic stressors related to anthropogenic impacts that species must deal with in both terrestrial and aquatic ecosystems. Chemicals in natural ecosystems occur in concentrations from trace to high levels, and mostly as complex mixtures of hardly predictable toxicity (Fent, 2004). All climatic scenarios predict that both temperature and its variations will increase in the forthcoming decades, as will extreme climatic events, with side-effects on the phenology and geographical range of several species and on the interactions between species (Williams et al., 2007).

Based on various taxonomic groups representing diversity key-components for ecosystem functioning in terms of primary production and food chain links (photosynthetic microorganisms, plants, and invertebrates), this review aims to analyze and discuss the current 
knowledge on how organisms respond and adapt to these abiotic stressors from the molecular to the community level.

Several molecular mechanisms and physiological responses (e.g. chaperone proteins, energy allocation) are often highlighted in stress studies. In particular, the existence of a "minimal stress response proteome" across species (Kültz, 2005) suggests a potential uniformity in the stress responses of different species at the cellular level. The commonalities of stress responses at higher levels of organization (from individual to community), however, has not yet been clearly addressed. Evaluating environmentally realistic experimental and field studies, here, we develop a wider integrative view, taking into account ecosystem biodiversity and the diversity of anthropogenic-related stressors in order to i) compare how molecular and physiological mechanisms related to protection and repairing functions and energy allocation can impact the life history traits of organisms under exposure to environmental stressors, and ii) determine to what extent trait responses influence individual and population responses, and with what repercussions on communities and ecosystems (Fig. 1). Commonalities in stress responses become less obvious at higher levels of biological organization as consequences of evolutionary distance and environmental complexity (particularly involving stress interactions as well as species/biotic interactions) but still remain connected via their energetic based origins.

\section{Molecular and cellular levels: how analogous are responses to abiotic stressors?}

\subsection{Do abiotic stressors induce similar mechanisms across taxa to protect cell integrity?}

At the cellular level, abiotic stressors cause metabolic imbalances, cascading effects on biochemical and physiological processes, and in severe cases, cellular death. Stress-induced injuries can occur directly by altering the biochemical structures and associated functions of biological molecules, or indirectly through the variation of osmotic pressure, the production 
of toxic metabolites and free radicals, the generation of oxidative stress, or the modification of signaling pathways (Couée et al., 2006; Guy et al., 2008; Srivastava et al., 2013; Teets and Denlinger, 2013). Chemicals such as pesticides strongly affect enzyme activities, the balance of reactive oxygen species (ROS) and cell communication, independently of their specific molecular targets (Couée et al., 2006; Brulle et al., 2009; Ramel et al., 2009a; Bouetard et al., 2013). Thermal stresses have considerable effects on the stability of nucleic acids and proteins, enzyme activities, and the fluidity of biological membranes (Kültz, 2005; Pierce et al., 2005).

Comparing various taxa, Kültz (2005) demonstrated that photosynthetic microorganisms, plants, and invertebrates share approximately three hundred proteins that are involved in cellular stress responses, highlighting a high degree of uniformity among species. This "minimal stress response proteome" seems to reflect the limited number of stress responses that have evolved among taxa to efficiently counteract the adverse endogenous effects of environmental stressors. Indeed, those proteins are involved in the protection (detoxification and excretion, damage sensing and repairing) of the same cellular functions (cell integrity, cell cycle or apoptosis, nucleic acid-related processes, metabolism and energy homeostasis, and redox status) across taxa, suggesting that similarity of responses at the cellular level may thus be connected to similarity of cellular organization and functions at the molecular level. This "minimal stress response proteome" constituted a first basis on which to analyze the commonality of stress responses among key taxa of ecosystem functioning in a context of anthropogenic-related stressors.

Ubiquitous mechanisms of stress response have evolved in order to limit or to repair abiotic stress-related damage to DNA, protein, and phospholipid native conformation (Kültz, 2005; Moller et al., 2007). The constitutive or induced expression of chaperone proteins, such as heat shock proteins (HSPs, HSCs), is one of the most ubiquitous and evolutionarily conserved 
mechanisms among organisms. Chaperone proteins facilitate the correct folding of proteins in statu nascendi or the refolding of damaged ones upon exposure to a wide range of environmental stressors (Hightower, 1991; Timperio et al., 2008; Zhao and Jones, 2012; Srivastava et al., 2013). HSP induction has thus been reported in diverse organisms exposed to a large variety of stressful conditions (e.g. pesticides, metals, salts, drought, heat, cold, UV radiation, and diseases), all causing protein denaturation, which is the genuine inducer (e.g. Slabas et al., 2006; Kim et al., 2007; Timperio et al., 2008; Bouetard et al., 2013; Srivastava et al., 2013; Peñuelas et al., 2013).

Detection of DNA damages triggers DNA repair mechanisms through the transcriptional and/or post-transcriptional induction of a variety of DNA repair and recombination (DRR) genes (Kimura and Sakaguchi, 2006). Completed genome sequences from prokaryotic and eukaryotic organisms reveal a large proportion of DRR genes to be conserved, although phylum-specific mechanisms of DNA repair have also been proposed (Kimura and Sakaguchi, 2006). Thus, whereas plant genomes contain DRR eukaryotic homologs (closer to human than to yeast counterparts) and some prokaryotic-specific genes (e.g., RadA and FPG homologues), they also exhibit several plant-specific DRR genes (e.g. Rad2 family nucleases) (Kimura and Sakaguchi, 2006). Nevertheless, in species as different as cyanobacteria, plants, and invertebrates, DNA damage due to temperature and chemical stressors generally increases DNA repair mechanisms (base or nucleotide excision repair, non-homologous end joining and homologous recombination), with tolerance being partly related to the induction of similar DNA and RNA processing mechanisms (Loeschcke et al., 2004; Kültz, 2005; Pierce et al., 2005; Slabas et al., 2006; Ramel et al., 2007; Owen et al., 2008; Brulle et al., 2009). Oxidative stress, which corresponds to an imbalance of ROS (e.g. superoxide, hydrogen peroxide, nitric oxides) production and antioxidant mechanisms in the cell, represents a common direct or side effect in stress-exposed organisms (Couée et al., 2006; Ramel et al., 
2009a; Lalouette et al., 2011; Teets et al., 2012; Bouetard et al., 2013; Srivastava et al., 2013). The accumulation of ROS and related products is generally rapidly counteracted by the enhancement of antioxidant processes to avoid irreversible cellular damage and death. Thus, from cyanobacteria to plants and in aquatic and terrestrial invertebrates, chemical and thermal stressors strongly increase the enzymes involved in ROS scavenging [e.g. superoxide dismutases (SOD), catalases (CAT), and peroxidases (POD)], and more broadly in oxidative stress responses (e.g. thioredoxin peroxidases), as well as the enzymes involved in regenerating the main cellular antioxidants (i.e. ascorbate, tocopherol, glutathione) (Guy et al., 2008; Latifi et al., 2009; Ramel et al., 2009a; Riaz et al., 2009; Lalouette et al., 2011; Bouetard et al., 2013). In particular, glutathione (GSH) is the major cellular thiol participating in enzymatic and non-enzymatic redox reactions in plants and animals to protect against oxidative damage (Doyotte et al., 1997; Ferrat et al., 2003). The up-regulation of genes encoding CATs, SODs and glutathione-S-transferases (GSTs) has been observed in heatexposed specimens of both plants and soil invertebrates thanks to genomic studies (Roelofs et al., 2008). Further, species or ecotypes exhibiting tolerance to chemical and thermal stressors in a wide range of taxa are characterized by higher capacities for ROS scavenging in comparison to their sensitive (non-tolerant) relatives (Blagojević, 2007; Roelofs et al., 2008; Ramel et al., 2009b; Srivastava et al., 2013). As stated by Kültz (2005), oxidative stress responses thus appear as an inevitable commonality across various taxa (photosynthetic microorganisms, plants, and invertebrates). Despite sharing similar antioxidative mechanisms, however, activities and preferred pathways differ between phyla. While ascorbate POD is the major $\mathrm{H}_{2} \mathrm{O}_{2}$ scavenging enzyme in plants, animals rely on CAT and glutathione POD (GSHPOD) to achieve this function (Fridovich, 1998; Latifi et al., 2009). Moreover, phototrophspecific nonenzymatic antioxidative pathways exist. Indeed, phototrophs are confronted with additional sources of ROS originating from photosynthesis, and have evolved synthesis of 
photosynthesis-related antioxidant compounds such as $\alpha$-tocopherols and carotenoids, which were also found to be involved in abiotic stress tolerance in plants (Arbona et al., 2013). Nevertheless, heterotroph organisms also benefit from $\alpha$-tocopherol- and carotenoid-related antioxidant compounds, such as vitamins $\mathrm{E}$ and $\mathrm{A}$, which are acquired via food consumption. Chemical detoxification or degradation processes at least partially precondition most organisms' levels of chemical stress tolerance (Riaz et al., 2009; Russell et al., 2011). The most widely described xenobiotic detoxification pathways are known as xenome (detection, transport and detoxification of xenobiotics) and as Multi-Xenobiotic Resistance (export). These highly conserved pathways among phyla detoxify endogenous and exogenous compounds through their activation and subsequent conjugation to glutathione, sulfate, or sugars, and/or through their removal from cytosol by elimination or storage as inactive compounds (Rea et al., 1998; Bard, 2000; Brulle et al., 2009; Riaz et al., 2009; Edwards et al., 2011; Russell et al., 2011). Corresponding proteins [cytochrome P450 monooxygenases (Cyt P450s), and transferases: GSTs, UDP-sugar dependent glycosyl- or glucuronosyl-transferases, sulfotransferases, esterases, among others] belong to enzyme families widely involved in cell metabolism and biotic stress responses, such as those mediated through allelochemicals or natural toxins (Leaver et al., 1993; Kreuz et al., 1996; Rea et al., 1998; Lindblom and Dodd, 2006; Li et al., 2007; Edwards et al., 2011). The broad substrate specificity of these enzymes enables organisms to detoxify xenobiotics via novel associations of pre-existing enzymes [“patchwork model" or "silent metabolism" (Copley, 2000; Lewinsohn and Gijzen, 2009)]. Analogies in the function and amino acid sequences of these enzymes between organisms led to the conclusion that these xenome components emerged early in the evolutionary process (Sandermann, 1992), explaining the commonality of detoxification pathways among phyla. Striking similarities are thus found between plants and animals with respect to the involvement of Cyt P450s and conjugation to glutathione (Sandermann, 1992). Differences 
are observed in major types of conjugation, however, in that xenobiotics are merely glucuronated in animals but glucosylated in plants, likely resulting from specificities of the energetic metabolism of these taxa as shown in several examples of herbicide conjugates (Kreuz et al., 1996). Finally, the fate of conjugates differs, being exported in animals by external secretion but stored in the vacuole or associated with the apoplast in plants (Kreuz et al., 1996). Recent investigations, however, highlighted that plant species such as Arabidopsis thaliana and Nicotiana tabacum could release significant amounts of xenobiotic by-products as their glucoside forms (Taguchi et al., 2010), thus reducing the gap of commonality across phyla. Other detoxification pathways involving photosynthesis-dependent processes or specific enzymes have even been highlighted in cyanobacteria (Thengodkar and Sivakami, 2010). Such a distinction from eukaryotes is not surprising because bacteria have evolved a broad biochemical repertoire to break down and mineralize exogenous compounds, whereas detoxifying and excretion mechanisms are the prevailing pathways in eukaryotes (Russell et al., 2011).

Stress may also lead to the induction of programmed cell death (PCD) such as apoptosis to eliminate damaged cells. Initially described in metazoans, plants, yeast and protozoa (Ameisen, 1996; Ishikawa et al., 2011), PCD has also been demonstrated in unicellular phytoplankton and cyanobacteria (Bidle and Fallkowski, 2004; Zuppini et al., 2007). PCD is mainly driven by effectors such as caspase proteins, which are tightly regulated through the involvement of pro- or anti-apoptotic proteins (Raff, 1992; Ishikawa et al., 2011). Several actors in and regulators of apoptosis process have been isolated in animal lineages from nematodes to mammals (Kumar, 2007; Oberst et al., 2008; Zhuang et al., 2011), and in plants (Morita-Yamamuro et al., 2005; Blanvillain et al., 2011). Thus, PCD hallmarks, including DNA laddering, mitochondrial cytochrome $\mathrm{C}$ release, loss of membrane asymmetry, and chromatin condensation, as well as caspase or -like activities and apoptosis inhibitors, were 
shown to be similar in plant and animal cells, proving a high level of commonality among apoptotic mechanisms (reviewed in Danon et al., 2000; Zuppini et al., 2007; Ishikawa et al., 2011; Van Doorn et al., 2011). Organisms' sensitivity or tolerance to environmentally relevant abiotic stressors may also be associated with the activation or inhibition of cell death (Ramel et al., 2007; Teets et al., 2012). This relationship remains conditional, however, as tolerance or sensitivity may result from several molecular processes among which cell death may have variable weight.

These results clearly highlight that major anthropogenic-related stressors such as chemicals and thermal changes induce similar protection mechanisms at the molecular level in species as diverse as photosynthetic microorganisms, plants, and invertebrates (Fig. 1). Stress responses are also closely related to cell or organism metabolisms, however, which can be deeply imbalanced by stressors.

\subsection{Do abiotic stressors similarly affect the metabolic status of organisms across taxa?}

Abiotic stressors affect metabolic responses and associated genomic regulations in organisms, with several metabolite classes typically being accumulated or depleted in response to a range of stressful conditions (Lankadurai et al., 2013). Metabolomics simultaneously analyzes the variations of a high number of metabolites, and represents a relevant tool for studying such stress responses. Indeed, metabolic profiles, which result from gene transcription and protein functions, constitute signatures of how synthesis and degradation pathways interact and are regulated (Lankadurai et al., 2013). Based on energy allocation models, maintenance costs increase under stressful conditions because maintaining cellular homeostasis requires additional energy, placing energetic metabolism in a central position in biological systems (Calow, 1991). Thus, carbohydrate metabolism is one of the first metabolic processes affected by chemical and thermal stressors, which modify sugar metabolism from gene expression to 
enzyme activity in diverse organisms, e.g. photosynthetic prokaryotes, plants, and invertebrates (Slabas et al., 2006; Ramel et al., 2007; Guy et al., 2008; Brulle et al., 2009; Thornton et al., 2010; Krasensky and Jonak, 2012; Teets et al., 2012; Arbona et al., 2013). The resulting decrease in carbon storage compounds (starch for plants, glycogen for invertebrates) is most often associated with increased levels of circulating sugars such as fructose, glucose, sucrose, and trehalose (Teets et al., 2012; Arbona et al., 2013), except for species exhibiting naturally high amounts of such compounds, such as cold-adapted plants (e.g. Zuñiga et al., 1996; Hennion and Bouchereau, 1998; Aubert et al., 1999). These sugars constitute a quick energy source, allowing organisms to rapidly face increased energetic needs induced by stress, and also represent important substrates for several biosynthesis pathways (amino or nucleic acids, secondary metabolites). Together with other metabolite families, sugars also belong to the group of compatible solutes [e.g. mono-, di-, and oligosaccharides, the amino acid proline, and some polyols (glycerol, galactinol, inositol, mannitol, and sorbitol)], which are widely accumulated in a large range of organisms facing environmental perturbations, and which are used for macromolecule stabilization, osmoprotection, and ROS scavenging (Hennion and Bouchereau, 1998; Ober, 2005; Roelofs et al., 2008; Krasensky and Jonak, 2012; Arbona et al., 2013; Lankadurai et al., 2013; Srivastava et al., 2013; Peñuelas et al., 2013).

The pool of amino acids is at the center of metabolic activity during stress response, and abiotic stressors often result in the accumulation of several amino acids originating from either de novo synthesis or protein breakdown (Krasensky and Jonak, 2012; Lankadurai et al., 2013). Thermal stressors increase the level of several circulating amino acids, particularly those derived from oxaloacetate and pyruvate (Ala, Asp, Ile, Leu, Pro, Thr, Val) (Renault et al., 2006; Guy et al., 2008). Elevated temperatures trigger the accumulation of beta-alanine in both plants and insects (Guy et al., 2008), and a causal relationship between increased proline 
levels and stress tolerance has also been suggested in diverse taxa (Fatma et al., 2007; Koštál et al., 2012). Even if amino acid accumulation appears to be ubiquitous in plants and insects facing thermal stressors, it has not yet been clarified whether such accumulation represents an adaptive response to counteract endogenous stress effects or if it simply depicts the stressinduced metabolic imbalance of some specific metabolic pathways.

Secondary metabolites are also of great importance in stress defense processes. Among them, polyamines, which constitute the major cellular polycationic compounds in living organisms, were found to be important elements of response mechanisms to various stressors (Rhee et al., 2007). Studies using the diversity of both plants (Poaceae, Ranunculaceae, Rosaceae, Brassicaceae, Asteraceae) and abiotic environments (high soil salinity, high soil water saturation, high altitude) in the Kerguelen Islands demonstrated that species undergo the same relative shifts in amine composition across environments despite their specific basal amine composition (Hennion et al., 2012). The accumulation of polyamines such as putrescine upon exposure to stress related to heat, cold, salt or pesticide seems to constitute a general pattern of stress responses in a wide diversity of taxa (Rhee et al., 2007; Michaud et al., 2008; Gupta et al., 2013).

Comparative studies using closely related species (e.g. Brassicaceae as Pringlea antiscorbutica and A. thaliana) or habitat ecotypes of the same species (e.g. A. thaliana, Thellungiella sp. and Bromus sp. for plants, and Drosophila melanogaster for insects) have demonstrated positive correlations between the tolerance to abiotic stressors (cold and heat, dehydration, salt, herbicide) and amounts of metabolites such as soluble sugars, polyols, proline, and polyamines (Hennion and Bouchereau, 1998; Gicquiaud et al., 2002; Hummel et al., 2004; Couée et al., 2006; Rhee et al., 2007; Guy et al., 2008; Ramel et al., 2009b; Colinet et al., 2012; Krasensky and Jonak, 2012; Lee et al., 2012). Interestingly, and similarly to the expression of stress proteins, metabolite accumulation resulting in abiotic stress tolerance can 
be constitutive or stimulated by environmental stressors (Gicquiaud et al., 2002; Hummel et al., 2004; Guy et al., 2008; Ramel et al., 2009b). Increased synthesis and the accumulation of key metabolites such as compatible solutes is also part of the acclimation processes, allowing organisms to undergo and better tolerate more severe stress.

To conclude, common metabolic responses to abiotic stressors do exist across phyla; however, some of the common stress-related metabolites may display different functions across species. For instance, trehalose is found in high levels in invertebrates and represents an important compatible solute, while its low levels in plants are not in accordance with such a role but rather highlight its function as a key stress signal (Krasensky and Jonak, 2012; Lunn et al., 2014). Conversely, stress responses do not necessarily require the accumulation of specific metabolites, but rather the accumulation of metabolites of specific functions that allow the maintenance of cell integrity. Moreover, in some cases, the flux through a metabolic pathway rather than accumulation of metabolites per se may contribute to stress tolerance (Krasensky and Jonak, 2012). It thus seems that species have developed a whole range of strategies to adapt to unfavorable conditions. However, these strategies often converged towards similar solutions that may be ancestral or may have evolved several times independently (Fig. 1).

\section{Does the commonality of stress responses observed at the molecular and cellular levels translate to higher organization levels, from individuals to populations?}

Although the commonality of stress responses to chemical and thermal stressors among taxa is evident at the molecular and cellular scales, it remains less obvious at higher levels of organization as shown in this part.

3.1. Life history traits affected by abiotic stressors 
Whatever the taxon, all environmental stressors significantly affect individual performance, usually such that the effects increase with increased stress intensity and/or duration, potentially leading to death (Larcher, 2003; Roelofs et al., 2008; Colinet et al., 2015). Under sublethal stresses [no significant mortality within a population (Amice et al., 2008)], organisms incur a fitness cost in terms of metabolic resources (Fig. 1) because less energy becomes available for life history traits due to the costly molecular and cellular stress responses (e.g. Calow, 1991; Jager et al., 2014). Because energy is a limiting factor for organisms, both stress responses and the preservation of homeostasis will increase the energetic constraints applied to traits, and more specifically to trade-offs existing among traits. As a result of such additional trade-offs and depending on the degree of organisms' stress sensitivity (sensitivity, tolerance, resistance), some traits may be more affected than others, but without any observable commonality among all taxa (e.g. Smolders et al., 2004; Vila-Aiub et al., 2009; Wonkka et al., 2013).

In photosynthetic organisms, the molecular effects of chemical and thermal stressors result, at the individual level, in global growth inhibition (or dormancy) and photosynthesis impairment through decreased photosystem efficiency and chlorosis (Guanzon and Nakahara, 2002; Gustavson et al., 2003; González-Barreiro et al., 2004; Hummel et al., 2004; Ramel et al., 2007; Kaplan-Levy et al., 2010). Thus, in a wide variety of plants, traits relative to root and shoot growth (Hummel et al., 2004; Ramel et al., 2007, 2009b; Carpenter et al., 2012; Peñuelas et al., 2013; Serra et al., 2013, 2015), biomass (Cedergreen et al., 2004; Carpenter et al., 2012), and pigment contents (Serra et al., 2013, 2015) are negatively affected by such stressors. These traits, which include the widely used plant height, leaf size and surface leaf area, are among the plant stressor-responsive traits described by Cornelissen et al. (2003) that are involved in climate and defense/protection responses. Irrespectively of the potential available energy, chemical and thermal stressors may also impair plant reproduction processes 
with variations in the affected traits depending on stress and species; responses include early or delayed flowering, asynchrony of male and female reproductive development, defects in parental tissues and gametes, and male sterility, all resulting in a poor seed production (Zinn et al., 2010; Peñuelas et al., 2013; Boutin et al., 2014; Londo et al., 2014).

In invertebrates such as freshwater gastropods, insects, and cladocerans, chemical and thermal stressors may affect various traits linked to maintenance (e.g. immunological capacity, locomotion, longevity), commonly leading to impacts on growth (for juveniles) and fecundity (for adults) (e.g. Gérard et al., 2005; Oehlmann et al., 2008; Dao et al., 2010; Ismail et al., 2010; Renault, 2011). Traits affected by similar stressors can vary within the same species (e.g. Gérard and Poullain, 2005) or between closely related species (e.g. Streit and Peter, 1978). For example, while the herbicide atrazine decreases survival, fecundity and egg eclosion rate and concomitantly increases activity and ingestion in the freshwater gastropod Ancylus fluviatilis (Streit and Peter, 1978), similar atrazine exposure affects only the locomotor activity (but not growth and fecundity traits) of another freshwater gastropod Potamopyrgus antipodarum (Gérard and Poullain, 2005).

Stress effects on life history traits strongly depend on the developmental/phenological stage at which stressors are applied (seedlings vs. older plants, larvae/juveniles vs. adults) because of differences in stress sensitivity and resource/energy allocation patterns (e.g. Viougeas et al., 1995; Clark and Wilson, 2003; Gérard et al., 2005; Dao et al., 2010; Kallioniemi and Hanski, 2011; Seeland et al., 2013; Tardieu, 2013). Photosynthesis appears to be the first trait affected in fully developed plants exposed to various stressful conditions (e.g. warm and cold temperatures, herbicides, water and salt stresses) (Manuel et al., 1999; Roitsch, 1999; Saladin et al., 2003; Bloedner et al., 2007), whereas growth-related traits such as root and leaf length are more impacted than photosynthesis in young seedlings (Serra et al., 2013, 2015). This 
may be linked to the stress-related regulation of developmental program, meristem activities and reserve allocation to combat the stress instead to promote growth.

For invertebrates such as the butterfly Melitaea cinxia, a stressful decrease of temperature induces a decrease in the survival and growth of larvae, but impairs the locomotion (flight metabolism, running speed), fecundity and longevity of adults (Kallioniemi and Hanski, 2011). One surprising fact, however, is that the best thermal resistant genotypes in adults are not generally the best resistant in larvae (Kallioniemi and Hanski, 2011). Additionally, the time of stress exposure may affect later life stages as is the case for mosquitoes stressed as larvae: the size and longevity of adults were related to the temperature experienced at the early developmental stage (Muturi et al., 2011). Not surprising, chemical stressors first affect the most energy demanding pathways, which is growth in immature individuals versus fecundity for adults, even in animal taxa exhibiting continuous growth throughout their lives, such as most freshwater gastropods or crustaceans (e.g. Gérard et al., 2005; Dao et al., 2010). Our analysis of the literature also shows that most studies investigate only a few life-history traits in species (see, e.g. Cornelissen et al., 2003; Amice et al., 2008; Schmolke et al., 2010 for reviews). Thus, there is an obvious necessity to examine more traits simultaneously in future studies to rigorously measure the stress impacts at the individual level and draw clear conclusions about the level of commonality in the stress-affected traits or in their associated trade-offs. Nevertheless, using the energetic approach based on the Dynamic Energy Budget (DEB) theory, energy-related processes and the rearrangement of the energetic balance may be considered as one commonality of stress responses across taxa (e.g. Smolders et al., 2004; Baas et al., 2010; Martin et al., 2013). Indeed, general traits (growth, reproduction) were found to be similarly affected under stress exposure, with differences occurring in more specific traits in relation to consequent changes in resource allocation patterns between traits, 
which differ depending on species and developmental stage. Further researches are thus needed to understand the selective pressures originating this variability. Despite linking DEB models to population models has provided mechanistic basis for extrapolation (Jager et al., 2014), energy allocation may not cover all aspects of stress responses observed at the population level. Comprehensive understanding is still not reached and research is needed to clarify species specific response outcomes.

\subsection{Traits related to stress sensitivity versus tolerance/resistance across taxa}

Organisms' sensitivity to stressors is shown to be a function of their biology, and can be predicted on the basis of species traits such as morphology, life history, physiology and feeding ecology (Baird and van den Brink , 2007). Approaches based on life-history traits may thus allow to determine the specific vulnerability of populations in the field (e.g. Ansart et al., 2002; Baird and van den Brink, 2007; Liess and Beketov, 2011; Sandel and Dangremond, 2012).

According to the stress-size hypothesis, stressors are expected to favor smaller species from lower trophic levels and smaller individuals within populations (Odum, 1985; Ismail et al., 2012). Indeed, stress sensitivity increases with the trophic rank as shown in field studies for numerous taxa among grasses, microorganisms, zooplankton, and macroinvertebrates exposed to various stressors such as metal contamination and climate warming (Cattaneo et al., 1998; Voigt et al., 2003; MacLennan et al., 2012). The increase of stress sensitivity with body size is not always verified across taxa, however, as in the case of some grasses, freshwater molluscs and insects (Pip, 2000; Chown and Klock, 2001; Sandel and Dangremond, 2012), thus highlighting a weak generality between size traits and stress tolerance/resistance. For instance, tolerance/resistance to climate warming is indeed associated with small size for numerous species such as bacteria, phyto- and zooplankton, molluscs, insects, and fish (Pip, 2000; 
Daufresne et al., 2009; Ismail et al., 2012), but with large size for annual plant species (Sandel and Dangremond, 2012).

According to the specialization-disturbance hypothesis (Vazquez and Simberloff, 2002), generalist species seem more able than specialists to persist under stress exposure because their physiological plasticity allows them to be more tolerant (Davies et al., 2004; Richmond et al., 2005). Models simulating phytoplankton community dynamics under constant and cyclical environmental conditions confirmed this hypothesis by testing in silico generalistonly and specialist-only communities of four to 100 species (Richmond et al., 2005). Through a different approach quantifying the niche volume from coexistence data and ecological indicator values at a whole-region flora scale (707 plant species), specialists were shown to produce fewer descendants than generalists (Ozinga et al., 2013). The maintenance of generalist (versus specialist) species under exposure to abiotic stressors has also been reported in the field for many taxa as diverse as corals (database on general stress tolerance of 143 scleractinian species) or insects (thermal adaptation of six congeneric damselfly species) (Darling et al., 2012; Nilsson-Örtman et al., 2012). A relationship between the degree of specialization and species stress response, however, is not always observed (e.g. insects under a cyclically varying thermal environment, plant-pollinator systems under grazing), thus rejecting the specialization-disturbance hypothesis in some cases (Gilchrist, 1995; Vazquez and Simberloff, 2002). According to Colles et al. (2009), this hypothesis may be confirmed or rejected depending on the type of approach used (neoecological, paleoecological or phylogenetic). Indeed, most neoecological studies indicate that specialists suffer declines under recent environmental changes, which is confirmed by many paleoecological studies investigating longer-term survival. In contrast, phylogeneticists, studying the entire histories of lineages, showed that specialists are not trapped in evolutionary dead ends and can even give rise to generalists (Colles et al., 2009). 
Several other observations that do not lead to a theory at this time have shown that (i) stress tolerance and resistance may also be preferentially related to a combination of favorable traits, as frequently observed for a wide range of introduced species, including various photosynthetic organisms and metazoans, e.g. grasses (Sandel and Dangremond, 2012), dipterans such as the Liriomyza species (Kang et al., 2009), and gastropods such as $P$. antipodarum, potentially resulting in high competitive ability (Alonso and Castro-Diez, 2008); ii) stress tolerance and resistance are often selected at the expense of one or several other life-history traits (Vila-Aiub et al., 2009; Ismail et al., 2010; Cedergreen et al., 2004; Tang et al., 1997; Kliot and Ghanim, 2012; Wonkka et al., 2013). In most scenarios, energy related processes are impaired, leading to species-specific realization in the form of impaired growth and reproduction. No obvious generality emerges across taxa and types of abiotic stressors, however, for which one would expect common traits to be negatively correlated with stress resistance (or tolerance).

Nevertheless, it is worth noting that the acclimation (or acclimatization, hardening) process, which improves the development of stress tolerance/resistance, seems to exhibit higher commonality across taxa, despite species specificities of corresponding molecular mechanisms may exist. As an example, cold acclimation has been described in numerous species as different as cyanobacteria, plants, annelids, molluscs, nematodes, collembolans and insects, among which common cold-responsive molecular mechanisms were identified (Relina and Gulevsky, 2003; Carrasco et al., 2011). In the same way, hormetic effects (i.e. beneficial effects induced by exposure to low doses of a potentially toxic stressor) have also been described across a wide range of organisms (from bacteria to plants and metazoans) in response to exposure to at least 1000 different chemical and environmental stressors (Costantini et al., 2010 for review). This commonality of hormesis may remain unclear, 
however, as the potential a posteriori costs of such stress responses are generally unknown (Jager et al., 2014).

To conclude, the existence of a commonality of stress responses remains unclear at the population level based on current knowledge since all hypotheses proposed to discriminate tolerant/resistant populations are verified or denied depending on the examples considered. It is thus hard to decipher if this reflects a lack of knowledge, a problem associated with the different methods and biological end proxies used so far, or if it is the ecological reality.

\section{Discussion}

\subsection{Common or not common responses to abiotic stressors?}

The aim of this review is to synthesize the responses of a wide diversity of taxa (photosynthetic microorganisms, plants, and invertebrates) to abiotic stressors from the molecular to the population level in order to determine if similar response patterns emerge across species and/or lineages and across the different levels of biological organization. While focusing on major anthropogenic-associated stressors (chemical and thermal stressors), we demonstrated that common stress responses exist at the lowest levels (molecular and cellular), but that thereafter, this generality becomes less obvious with increasing organization levels (from individuals to populations) (Fig. 1). The generality observed at the molecular and cellular levels seems to indicate that stress responses, or at least the molecular (e.g. protein- or enzyme-encoding genes, signalization pathways, PCD, DRR) and cellular effectors (e.g. key metabolites, chaperones) of these stress responses, may have undergone strong selection to be conserved throughout evolution. This high degree of convergence across taxa highlights that organisms, or more specifically, key molecular pathways within organisms, have only a limited number of options to counter stress effects. In contrast, key processes of the organism life cycle (e.g. structural, developmental, and resource allocation patterns, life-history traits 
and trade-offs) mostly result from their macroevolutionary history (Hennion et al., 2012). These evolutionary constraints, which integrate pleiotropic mechanisms, genetic linkages, complex regulatory networks, and the resulting biology of organisms, may lead to strong divergences in stress responses across taxa, in spite of the demonstrated similarity at the molecular and cellular levels (Roelofs et al., 2008; Hennion et al., 2012) and the energetic responses observed (energy availability and allocation) that could be one way to view commonalities across taxa. Thus, an increasing divergence in stress responses may be expected with increasing phylogenetic distance, particularly when considering differences in key processes between organisms such as plants and animals (e.g. Huey et al., 2002). Although some stress response divergences are observed between taxa, however, a certain level of commonality seems to persist regarding the growth and reproductive traits affected by stressors.

Stress responses and degree of sensitivity, however, have been found to differ between strains/populations or closely related species (e.g. Hummel et al., 2004; Ekschmitt and Korthals, 2006). In such cases, species' adaptation levels and stress recovery capabilities may explain the early divergence between close species (Hummel et al., 2004; Roelofs et al., 2008; Gustavson et al., 2003; Carpenter et al., 2012). As stated by Lütz (2010), if species or communities are strongly adapted to a particular regime of stressors, they should not be regarded as stressed under such an environment. In addition, similar short-term stress responses are not always linked to similar levels of and times to recovery after stressor exposure (depending on reversible $v s$. irreversible effects of stress on each species) (Gustavson et al., 2003; Carpenter et al., 2012), therefore differently affecting population dynamics (Lance et al., 2011). Such differences in stress responses may result from the recent history of individuals forming populations in terms of events of stressor exposure, which may have modified their adaptive potential. Indeed, stresses occurring during periods that are 
shorter than an organism's life span strongly select for reversible phenotypic plasticity inducing shifts in behavioral, physiological, life-history or morphological traits (Gabriel, 2005). Stresses also drive micro-evolutionary processes in species, leading to both genetic and phenotypic diversity and the selection of genetically or epigenetically inherited tolerance in exposed populations. These processes allow the persistence of populations inhabiting environments that become degraded (Medina et al., 2007; Angers et al., 2010; Peñuelas et al., 2013). Thus, disappearance of similarity in stress responses across high (vs. low) organization levels may be explained by both macroevolution (at or above the species level) and phenotypic plasticity and microevolution (within a species or population) (Fig. 1).

\subsection{Impact of stress responses at the community level: species vs. functional diversity}

In the field, communities are exposed to multiple concomitant stressors (both abiotic and biotic) to which they can respond by resistance (i.e. remaining at equilibrium), resilience (i.e. returning to equilibrium after being stressed) or disappearance of the most sensitive species, potentially resulting in the decline of community diversity or the modification of species' relative abundance (Connell and Sousa, 1983; Vinebrooke et al., 2004; Gérard et al., 2008) (Fig. 1). Even if the effects of multiple stressors on communities are often masked by numerous confounding factors such as biotic interactions (e.g. intra- and inter-specific competition, facilitation, and predation), abiotic stressors have been shown to shape biodiversity patterns in communities and change the relative abundance of functional groups with subsequent consequences on higher trophic levels (e.g. Rohr and Crumrine, 2005; Mouthon and Daufresne, 2006; Pannard et al., 2009; Feio et al., 2010; Sundermann et al., 2013; Rubal et al., 2014). Community structures vary naturally from year to year, but changes in the richness and evenness of taxa are much larger and more unpredictable in stressed environments (e.g. Feio et al., 2010). 
Few hypotheses have been proposed to explain community responses (resistance, resilience, or decline) to environmental stressors. According to the insurance hypothesis, communities with high biodiversity have a better ability to resist stressor exposure because many species provide greater guarantees that some of them will maintain functioning even if others fail (Yachi and Loreau, 1999). This insurance hypothesis is of particular relevance because the mechanisms by which diversity may influence ecosystem functioning are related to the functional attributes of species rather than to species richness itself (e.g. Medina et al., 2007). Community responses may also depend on interactions between concomitant responses to multiple abiotic and biotic stressors, which occur in realistic field situations. Co-tolerance, i.e. correlations between the abilities of species (or individuals) to tolerate each stressor (Vinebrooke et al., 2004), may influence the global stress responses of species and communities. At the community scale, biotic interactions may also modify species' responses to environmental stressors compared to those observed in isolated species, leading to failures in predicting stress responses in the field (Bérard et al., 1999; Dalton and Boutin, 2010; Grassein et al., 2014). Based on the environmental stress model (Menge and Sutherland, 1987), competition becomes more important in structuring communities as abiotic stress level reduces, and predation is the main biotic interaction regulating community structure when stress level is low. According to the stress gradient hypothesis (Bertness and Callaway, 1994), an increased stress level in an ecosystem tends to select positive biotic interactions such as facilitation and limit negative interactions such as competition. However, this hypothesis may also be not verified depending on communities and spatial scale (Maestre et al., 2010).

To conclude, the commonality of stress responses seems less apparent at the community level because of highly complex and variable biotic and abiotic interactions occurring under multistress and multi-species conditions (Fig. 1). 


\subsection{What are the relevant markers to study ecosystem responses to abiotic stressors?}

Stress effects on ecosystems appear to be difficult to evaluate and predict due to the highly complex network of abiotic and biotic interactions resulting from the multi-stress and multispecies conditions previously observed at the community level. Ecosystem responses to chemicals, for instance, depend on multiple factors such as bioavailability, the biological targets of chemicals and associated effects, detoxification, the tolerance and recovery capabilities of each species, migration rates, extinction and recolonization dynamics, and type of habitat (Relyea and Hoverman, 2006).

Despite this complexity, measuring ecosystem functions (e.g. organic matter decomposition, nitrogen mineralization, carbon fixation) is increasingly being recognized as a potent tool to assess ecosystem health and services and as having value for human societies (e.g. Park et al., 2008; De Silva et al., 2010; MacKnight et al., 2012). Because maintaining such ecosystem functions may be related to the maintenance of high functional diversity (Medina et al., 2007), one way to study ecosystem stress responses could be to analyze potential trade-offs related to the development of tolerance in functional traits (Fig. 1). Predicting the repercussions of stressors on ecosystems could also be based partially on the molecular commonality of stress responses. Indeed, ecosystem functions are closely related to gene and protein expression, enzyme activity and metabolic fluxes, which may thus represent relevant biomarkers weakly submitted to trade-offs in comparison to higher levels of organization (Fig. 1). Both molecular stress response pathways and functional traits could thus represent functional markers to overcome scale transfer in stress ecology. Because stress response variability is partly related to multi-stress interactions, however, such markers would need to be further investigated under multi-stress contexts. Indeed, despite several studies demonstrating the importance of synergistic effects between abiotic stressors (e.g. Fent, 2004; Faria et al., 2010; Holmstrup et al., 2010), there are considerable gaps for numerous stressor interactions and 
effects, and there is insufficient quantitative evidence to suggest that the prevailing type of stressor interaction is synergistic (Ban et al., 2014). Thus, the impact of combined stressors at different organization levels is in urgent need of acute consideration by researchers, particularly in the present context of climate change, as chemical toxicity is generally shown to increase with increasing temperature (e.g. Moe et al., 2013; Heugens et al., 2001).

\section{Conclusion}

Due to increasing anthropogenic activities, organisms suffer from exposure to diverse stressors (abiotic/biotic/climatic) in their natural environments, mostly through combinations of stressors (multi-stress conditions) that vary in time and intensity.

This review focuses on the commonality of the repertoire evolved by organisms from both terrestrial and aquatic ecosystems (ranging from photosynthetic microorganisms to plants and invertebrates) to combat chemical and thermal stressors.

Given the similarity in cellular structures and functionalities across taxa, similar stresses evoke similar protection mechanisms at the molecular and cellular levels with respect to detoxification/excretion, the prevention and mending of damage, and similar metabolomic changes for energy allocation, secondary metabolites or compatible solute accumulation. At the individual and population levels, however, similarities become less obvious. Whereas general traits connected to energy resource management (growth, reproduction) seem similarly affected under stress exposure, differences occur in more specific traits due to both macroevolution (at or above the species level) and phenotypic plasticity and microevolution (within a species or population).

Abiotic stressors have been shown to shape biodiversity patterns in communities and change the relative abundance of functional groups with subsequent consequences for higher trophic levels. However, communities with high biodiversity are better equipped to resist stressor 
exposure. This diversity and complexity of communities makes it more difficult to see commonalities in stress responses and knowledge at high organization levels is still lacking to clearly answer to the commonality question.

Ecosystem responses to chemical and thermal stressors are the result of a highly complex network of multi-stress and multi-species interactions; ecosystem functions and services are therefore progressively considered as measures of its health status.

\section{Acknowledgments}

We thank Valérie Briand for her bibliographical assistance in researching and providing publications.

\section{References}

Alonso, A., Castro-Diez, P., 2008. What explains the invading success of the aquatic mud snail Potamopyrgus antipodarum (Hydrobiidae, Mollusca)? Hydrobiologia 614, 107116, doi:10.1007/s10750-008-9529-3.

Ameisen, J.C., 1996. The origin of programmed cell death. Science New Series 272, 12781279.

Amice, G., Vernon, P., Outreman, Y., Van Alphen, J., Van Baaren, J., 2008. Variability in responses to thermal stress in parasitoids. Ecological Entomology 33, 701-708, doi:10.1111/j.1365-2311.2008.01019.x.

Angers, B., Castonguay, E., Massicotte, R., 2010. Environmentally induced phenotypes and DNA methylation: how to deal with unpredictable conditions until the next generation and after. Molecular Ecology 19, 1283-1295, doi:10.1111/j.1365-294X.2010.04580.x. 
Ansart, A.,Vernon, P., Daguzan, J., 2002. Effects of a freezing event during hibernation on further survival, reproduction and growth in the partially freezing tolerant land snail Helix aspersa (Gastropoda: Helicidae). CryoLetters 23, 269-274.

Arbona, V., Manzi, M., de Ollas, C., Gómez-Cadenas, A., 2013. Metabolomics as a tool to investigate abiotic stress tolerance in plants. International Journal of Molecular Sciences 14, 4885-4911, doi:10.3390/ijms14034885.

Aubert, S., Assard, N., Boutin, J.P., Frenot, Y., Dorne, A.J., 1999. Carbon metabolism in the subantarctic Kerguelen cabbage Pringlea antiscorbutica R. Br.: environmental controls over carbohydrates contents and relation to phenology. Plant Cell Environment 22, 243254, doi: 10.1046/j.1365-3040.1999.00417.x.

Baas, J., Jager, T., Kooijman, B., 2010. A review of DEB theory in assessing toxic effects of mixtures. Science of the Total Environment 408, 3740-3745, doi:

10.1016/j.scitotenv.2009.09.037.

Baird, D.J, van den Brink, P.J., 2007. Using biological traits to predict species sensitivity to toxic substances. Ecotoxicology and Environmental Safety 67, 296-301, doi: 10.1016/j.ecoenv.2006.07.001.

Ban, S.S., Graham, N.A.J., Connolly, S.R., 2014. Evidence for multiple stressor interactions and effects on coral reefs. Global Change Biology 20, 681-697.

Bard, S.M., 2000. Multixenobiotic resistance as a cellular defense mechanism in aquatic organisms. Aquatic Toxicology 48, 357-389, doi:10.1016/S0166-445X(00)00088-6.

Beketov, M.A., Liess, M., 2012. Ecotoxicology and macroecology - Time for integration. Environmental Pollution 162, 247-254, doi: 10.1016/j.envpol.2011.11.011.

Bérard, A., Leboulanger, C., Pelte, T., 1999. Tolerance of Oscillatoria limnetica Lemmermann to atrazine in natural phytoplankton populations and in pure culture: 
influence of season and temperature. Archives of Environmental Contamination and Toxicology 37, 472-479.

Bertness, M.D., Callaway, R., 1994. Positive interactions in communities. Trends in Ecology \& Evolution 9, 191-193.

Bidle, K.D., Falkowski, P.G., 2004. Cell death in planktonic photosynthetic microorganisms. Nature Reviews Microbiology 2, 643-655.

Blagojević, D.P., 2007. Antioxidant systems in supporting environmental and programmed adaptations to low temperatures. CryoLetters 28, 137-150.

Blanvillain R., Young B., Cai Y.M., Hecht V., Varoquaux F., Delorme V., Lancelin J.M., Delseny M., Gallois P., 2011. The Arabidopsis peptide kiss of death is an inducer of programmed cell death. The EMBO Journal 30, 1173-1183, doi:10.1038/emboj.2011.14.

Bloedner, C., Goebel, C., Feussner, I., Gatz, C., Polle, A., 2007. Warm and cold parental reproductive environments affect seed properties, fitness, and cold responsiveness in Arabidopsis thaliana progenies. Plant Cell Environment 30, 165-175.

Bouetard, A., Besnard, A.L., Vassaux, D., Lagadic, L., Coutellec, M.A., 2013. Impact of the redox-cycling herbicide diquat on transcript expression and antioxidant enzymatic activities of the freshwater snail Lymnaea stagnalis. Aquatic Toxicology 126, 256-265, doi:10.1016/j.aquatox.2012.11.013.

Boutin, C., Strandberg, B., Carpenter, D., Mathiassen, S.K., Thomas, P.J., 2014. Herbicide impacts on non-target plant reproduction: What are the toxicological and ecological implications? Environmental Pollution 185, 295-306, doi:

10.1016/j.envpol.2013.10.009.

Brulle, F., Morgan, A.J., Cocquerelle, C., Vandenbulcke, F., 2009. Transcriptomic underpinning of toxicant-mediated physiological function alterations in three terrestrial 
invertebrate taxa: a review. Environmental Pollution 158, 2793-2808, doi: 10.1016/j.envpol.2010.06.019.

Calow, P., 1991. Physiological costs of combating chemical toxicants: ecological implications. Comparative Biochemistry and Physiology C 100, 3-6, doi: 10.1016/07428413(91)90110-F.

Calow, P., 1999. Blackwell’s concise encyclopedia of ecology. Blackwell Science.

Carpenter, D., Boutin, C., Allison, J.E., 2012. Effects of chlorimuron ethyl on terrestrial and wetland plants: levels of, and time to recovery following sublethal exposure. Environment Pollution 172, 275-282, doi:10.1016/j.envpol.2012.09.007.

Carrasco, M.A., Tan, J.C., Duman, J.G., 2011. A cross-species compendium of proteins/gene products related to cold stress identified by bioinformatic approaches. Journal of Insect Physiology 57, 1127-1135, doi: 10.1016/j.jinsphys.2011.04.021.

Cattaneo, A., Asioli, A., Comoli, P., Manca, M., 1998. Organisms' response in a chronically polluted lake supports hypothesized link between stress and size. Limnology and Oceanography 43, 1938-1943.

Cedergreen, N., Streibig, N.J., Spliid, N.H., 2004. Species specific sensitivity of aquatic macrophytes towards herbicides. Ecotoxicology and Environmental Safety 58, 314-323, doi:10.1016/j.ecoenv.2004.04.002.

Clark, D.L., Wilson, M.V., 2003. Post-dispersal seed fates of four prairie species. American Journal of Botany 90, 730-735, doi:10.3732/ajb.90.5.730.

Chown, S.L., Klok, C.J., 2001. Habitat use, diet and body size of Heard Island weevils. Polar Biology 24, 706-712, doi: 10.1007/s003000100281.

Colinet, H., Larvor, V., Laparie, M., Renault, D., 2012. Exploring the plastic response to cold acclimation through metabolomics. Functional Ecology 26, 711-722, doi: j.13652435.2012.01985.x. 
Colinet, H., Sinclair, B.J., Vernon, P., Renault, D., 2015. Insects in fluctuating thermal environments. Annual Review of Entomology 60, 123-140.

Colles, A., Liow, L.H., Prinzing, A., 2009. Are specialists at risk under environmental change? Ecology Letters 12, 849-863, doi: 10.1111/j.1461-0248.2009.01336.x.

Connell, J.H, Sousa, W.P., 1983. On the evidence needed to judge ecological stability or persistence. The American Naturalist 121, 789-824.

Copley, S.D., 2000. Evolution of a metabolic pathway for degradation of a toxic xenobiotic: the patchwork approach. Trends in Biochemical Sciences 25: 261-5, doi:10.1016/S0968-0004(00)01562-0.

Cornelissen, J.H.C., Lavorel, S., Garnier, E., Diaz, S., Buchmann, N., Gurvich, D.E., Reich, P.B., ter Steege, H., Morgan, H.D., van der Heijden, M.G.A., Pausas, J.G., Poorter, H., 2003. A handbook of protocols for standardised and easy measurement of plant functional traits worldwide. Australian Journal of Botany 51, 335-380, doi: 10.1071/BT0 2124.

Costantini, D., Metcalfe, N.B., Monaghan, P., 2010. Ecological processes in a hormetic framework. Ecology Letters 13, 1435-1447, doi:10.1111/j.1461-0248.2010.01531.x.

Couée, I., Sulmon, C., Gouesbet, G., El Amrani, A., 2006. Involvement of soluble sugars in reactive oxygen species balance and responses to oxidative stress in plants. Journal of Experimental Botany 57, 449-59, doi :10.1093/jxb/erj027.

Dalton, R.L., Boutin, C., 2010. Comparison of the effects of glyphosate and atrazine herbicides on nontarget plants grown singly and in microcosms. Environmental Toxicology and Chemistry 29, 2304-2315, doi:10.1002/etc.277.

Danon, A., Delorme, V., Mailhac, N., Gallois, P., 2000. Plant programmed cell death: A common way to die. Plant Physiology and Biochemistry 38, 647-655, doi: http://dx.doi.org/10.1016/S0981-9428(00)01178-5. 
Dao, T.S., Do Hong, L.C., Wiegand, C., 2010. Chronic effects of cyanobacterial toxins on Daphnia magna and their offspring. Toxicon 55, 1244-1254, doi:10.1016/j.toxicon.2010.01.014.

Darling, E.S., Alvarez-Filip, L., Oliver, T.A., McClanahan, T.R., Côté, I.M., 2012. Evaluating life-history strategies of reef corals from species traits. Ecology Letters 15, 1378-1386, doi: 10.1111/j.1461-0248.2012.01861.x.

Daufresne, M., Lengfellner, K., Sommer, U., 2009. Global warming benefits the small in aquatic ecosystems. Proceedings of the National Academy of Sciences 106, 1278812793, doi:10.1073/pnas.0902080106.

Davies, K.F., Margules, C.R., Lawrence, J.F., 2004. A synergistic effect puts rare, specialized species at greater risk of extinction. Ecology 85, 265-271, doi:10.1890/03-0110.

De Silva, P.M., Pathiratne, A., van Straalen, N.M., van Gestel, C.A., 2010. Chlorpyrifos causes decreased organic matter decomposition by suppressing earthworm and termite communities in tropical soil. Environmental Pollution 158, 3041-3047, doi:10.1016/j.envpol.2010.06.032.

Doyotte, A., Cossu, C., Jacquin, M.C., Babut, M., Vaseur, P., 1997. Antioxidant enzymes, glutathione and lipid peroxidation as relevant biomarkers of experimental or field exposure in the gills and the digestive gland of the freshwater bivalve Unio tumidus. Aquatic Toxicology 39, 93-110.

Edwards, R., Dixon, D.P., Cummins, I., Brazier-Hicks, M., Skipsey, M., 2011. New perspectives on the metabolism and detoxification of synthetic compounds in plants. Organic Xenobiotics and Plants, Plant Ecophysiology 8, 125-148, doi: 10.1007/978-90481-9852-8_7.

Ekschmitt, K., Korthals, G.W., 2006. Nematodes as sentinels of heavy metals and organic toxicants in the soil. Journal of Nematology 38, 13-19. 
Faria, M., Lopez, M.A., Fernandez-Sanjuan, M., Lacorte, S., Barata, C., 2010. Comparative toxicity of single and combined mixtures of selected pollutants among larval stages of the native freshwater mussels (Unio elongatulus) and the invasive zebra mussel (Dreissena polymorpha). Science of the Total Environment 408, 2452-2458, doi:10.1016/j.scitotenv.2010.02.047.

Fatma, T., Khan, M.A., Choudhary, M., 2007. Impact of environmental pollution on cyanobacterial proline content. Journal of Applied Phycology 19, 625-629, doi:10.1007/s10811-007-9195-2.

Feio, M.J., Coimbra, C.N., Graca, M.A.S., Nichols, S.J., Norris, R.H., 2010. The influence of extreme climatic events and human disturbance on macroinvertebrate community patterns of a Mediterranean stream over $15 \mathrm{y}$. Journal of the North American Benthological Society 29, 1397-1409, doi:10.1899/09-158.1.

Fent, K., 2004. Ecotoxicological effects at contaminated sites. Toxicology 205, 223-240, doi:10.1016/j.tox.2004.06.060.

Ferrat, L., Pergent-Martini, C., Romeo, M., 2003. Assessment of the use of biomarkers in aquatic plants for the evaluation of environmental quality: application to seagrasses. Aquatic Toxicology 65, 187-204.

Fridovich, I., 1998. Oxygen toxicity: a radical explanation. Journal of Experimental Biology 201, 1203-1209, doi:10.3390/ijms14034885.

Gabriel, W., 2005. How stress selects for reversible phenotypic plasticity. Journal of Evolutionary Biology 18, 873-883, doi:10.1111/j.1420-9101.2005.00959.x.

Gérard, C., Poullain, V., 2005. Variation in the response of the invasive species Potamopyrgus antipodarum (Smith) to natural (cyanobacterial toxin) and anthropogenic (herbicide atrazine) stressors. Environmental Pollution 138, 28-33, doi:10.1016/j.envpol.2005.02.028. 
Gérard, C., Brient, L., Le Rouzic, B., 2005.Variation in the response of juvenile and adult gastropods (Lymnaea stagnalis) to cyanobacterial toxin (microcystin-LR). Environmental Toxicology 20, 592-596, doi:10.1002/tox.20147.

Gérard, C., Carpentier, A., Paillisson, J.M., 2008. Long-term dynamics and community structure of freshwater gastropods exposed to parasitism and other environmental stressors. Freshwater Biology 53, 470-484, doi:10.1111/j.1365-2427.2007.01912.x.

Gicquiaud, L., Hennion, F., Esnault, M.A., 2002. Physiological comparisons among four related Bromus species with varying ecological amplitude: polyamine and aromatic amine composition in response to salt spray and drought. Plant Biology 4, 746-753, doi: $10.1055 / \mathrm{s}-2002-37401$.

Gilchrist, G.W., 1995. Specialists and generalists in changing environments. I. Fitness landscapes of thermal sensitivity. The American Naturalist 146, 252-270, doi:10.1086/285797.

González-Barreiro, Ó., Rioboo, C., Cid, A., Herrero, C., 2004. Atrazine-induced chlorosis in Synechococcus elongatus cells. Archives of Environmental Contamination and Toxicology 46, 301-307, doi:10.1007/s00244-003-2149-z.

Grassein, F., Lavorel, S., Till-Bottraud, I., 2014. The importance of biotic interactions and local adaptation for plant response to environmental changes: field evidence along an elevational gradient. Global Change Biology, doi: 10.1111/gcb.12445.

Guanzon, N., Nakahara, H., 2002. Growth and photosynthesis inhibition by agricultural pesticides in three freshwater microalgae. Fisheries Science 68, 144-151, doi: 10.1046/j.1444-2906.2002.00400.x.

Gupta, K., Dey, A., Gupta, B., 2013. Plant polyamines in abiotic stress responses. Acta Physiologiae Plantarum. 35, 2015-2036, doi: 10.1007/s11738-013-1239-4. 
Gustavson, K., Møhlenberg, F., Schlüter, L., 2003. Effects of exposure duration of herbicides on natural stream periphyton communities and recovery. Archives of Environmental Contamination and Toxicology 45, 48-58, doi:10.1007/s00244-002-0079-9.

Guy, C., Kaplan, F., Kopka, J., Selbig, J., Hincha, D.K., 2008. Metabolomics of temperature stress. Physiologia Plantarum 132, 220-35, doi:10.1111/j.1399-3054.2007.00999.x.

Hennion, F., Bouchereau, A., 1998. Accumulation of organic and inorganic solutes in the subantarctic cruciferous species Pringlea antiscorbutica in response to saline and cold stresses. Polar Biology 20, 281-291, doi:10.1007/s003000050304.

Hennion, F., Bouchereau, A., Gauthier, C., Hermant, M., Vernon, P., Prinzing, A., 2012. Variation in amine composition in plant species: how it integrates macroevolutionary and environmental signals. American Journal of Botany 99, 36-45, doi:10.3732/ajb.1100211.

Heugens, E.H.W., Hendricks, A.J., Dekker, T., van Straalen, N.M., Admiraal, W., 2001. A review of the effects of multiple stressors on aquatic organisms and analysis of uncertainly factors for use in risk assessment. Critical Reviews in Toxicology 31, 247284.

Hightower, L.E., 1991. Heat shock, stress proteins, chaperones, and proteotoxicity. Cell 66, 191-197, doi: 10.1016/0092-8674(91)90611-2.

Holmstrup, M., Bindesbol, A.M., Osstingh, G.J., Duschl, A., Scheil, V., Köhler, H.R., Loureiro, S., Soeares, A.M., Ferreira, A.L., Kienle, C et al. 2010. Interactions between effects of environmental chemicals and natural stressors: a review. Science of the Total Environment 408, 3746-3762, doi:10.1016/j.scitotenv.2010.01.043.

Huey, R.B., Carlson, M., Crozier, L., Frazier, M., Hamilton, H., Harley, C., Hoang, A., Kingsolver, J.G., 2002. Plants versus animals: do they deal with stress in different ways? Integrative and Comparative Biology 42, 415-423, doi:10.1093/icb/42.3.415. 
Hummel, I., El Amrani, A., Gouesbet, G., Hennion, F., Couée, I., 2004. Involvement of polyamines in the interacting effects of low temperature and mineral supply on Pringlea antiscorbutica (Kerguelen cabbage) seedlings. Journal of Experimental Botany 55, 1125-34, doi:10.1093/jxb/erh126.

Ishikawa, T., Watanabe, N., Nagano, M., Kawai-Yamada, M., Lam, E., 2011. Bax inhibitor-1: a highly conserved endoplasmic reticulum-resident cell death suppressor. Cell Death \& Differentiation 18, 1271-1278, doi:10.1038/cdd.2011.59.

Ismail, M., Vernon, P., Hance, T., van Baaren, J.,2010.Physiological costs of cold exposure on the parasitoid Aphidius ervi, without selection pressure and under constant or fluctuating temperatures. Biocontrol 55, 729-740, doi:10.1007/s10526-010-9303-0.

Ismail, M., Vernon, P., Hance, T., Pierre, J.S., van Baaren, J., 2012. What are the possible benefits of small size for energy-constrained ectotherms in cold stress conditions? Oikos 121, 2072-2080, doi: 10.1111/j.1600-0706.2012.20582.x.

Jager, T., Barsi, A., Hamda, N.T., Martin, B.T., Zimmer, E.I., Ducrot, V., 2014. Dynamic energy budgets in population ecotoxicology: applications and outlook. Ecological Modelling 280, 140-147, DOI: 10.1016/j.ecolmodel.2013.06.024.

Kallioniemi, E., Hanski, I., 2011. Interactive effects of Pgi genotype and temperature on larval growth and survival in the Glanville fritillary butterfly. Functional Ecology 25, 1032-1039, doi:10.1111/j.1365-2435.2011.01854.x.

Kang, L., Chen, B., Wei, J.N., Liu, T.X., 2009. Roles of thermal adaptation and chemical ecology in Liriomyza distribution and control. Annual Review of Entomology 54, $127-$ 145, doi:10.1146/annurev.ento.54.110807.090507.

Kaplan-Levy, R.N., Hadas, O., Summers, M.L., Rücker, J., Sukenik, A., 2010. Akinetes: dormant cells of cyanobacteria. In: Dormancy and resistance in harsh environments. Topics in Current Genetics 21, 5-27, doi:10.1007/978-3-642-12422-8_2. 
Kim, H.J., Hwang, N.R., Lee, K.J., 2007. Heat shock responses for understanding diseases of protein denaturation. Molecules and Cells 23, 123-131.

Kimura, S., Sakaguchi, K., 2006. DNA repair in plants. Chemical Reviews 106, 753-766, doi: $10.1021 /$ cr040482n.

Kliot, A., Ghanim, M., 2012.Fitness costs associated with insecticide resistance. Pest Management Science 68, 1431-1437, doi:10.1021/cr040482n.

Koštál, V., Šimek, P., Zahradníčková, H., Cimlová, J., Štětina, T., 2012. Conversion of the chill susceptible fruit fly larva (Drosophila melanogaster) to a freeze tolerant organism. Proceedings of the National Academy of Sciences 109, 3270-3274, doi:10.1073/pnas.1119986109.

Krasensky, J., Jonak, C.,2012. Drought, salt, and temperature stress-induced metabolic rearrangements and regulatory networks. Journal of Experimental Botany 63, 15931608, doi:10.1093/jxb/err460.

Kreuz, K., Tommasini, R., Martinoia, E., 1996. Old enzymes for a new job (herbicide detoxification in plants). Plant Physiology 111, 349-353.

Kültz, D., 2005. Molecular and evolutionary basis of the cellular stress response. Annual Review of Physiology 67, 225-257, doi:10.1146/annurev.physiol.67.040403.103635.

Kumar, S., 2007. Caspase function in programmed cell death. Cell Death \& Differentiation $14,32-43$.

Lalouette, L., Williams, C.M., Hervant, F., Sinclair, B.J., Renault, D., 2011. Metabolic rate and oxidative stress in insects exposed to low temperature thermal fluctuations. Comparative Biochemistry and Physiology A,158, 229-234, doi:10.1016/j.cbpa.2010.11.007.

Lance, E., Alonzo, F., Tanguy, M., Gérard, C., Bormans, M., 2011. Impact of microcystinproducing cyanobacteria on reproductive success of Lymnaea stagnalis (Gastropoda, 
Pulmonata) and predicted consequences at the population level. Ecotoxicology 20, 719730, doi: 10.1007/s10646-011-0613-5.

Lankadurai, B., Nagato, E., Simpson, M., 2013. Environmental metabolomics: an emerging approach to study organism responses to environmental stressors. Environmental Reviews 21, 180-205, doi: 10.1139/er-2013-0011.

Larcher, W., 2003. Physiological Plant Ecology, 4th ed. Berlin: Springer.

Latifi, A., Ruiz, M., Zhang, C.C., 2009. Oxidative stress in cyanobacteria. FEMS Microbiology Reviews 33, 258-278, doi:10.1111/j.1574-6976.2008.00134.x.

Leaver, M.J., Scott, K., George, S.G., 1993. Cloning and characterization of the major hepatic glutathione S-transferase from a marine teleost flatfish, the plaice (Pleuronectes platessa), with structural similarities to plant, insect and mammalian Theta class isoenzymes. Biochemical Journal 292,189-195.

Lee, Y.P., Babakov, A., de Boer, B., Zuther, E., Hincha, D.K., 2012. Comparison of freezing tolerance, compatible solutes and polyamines in geographically diverse collections of Thellungiella sp. and Arabidopsis thaliana accessions. BMC Plant Biology 12, 131-141, doi:10.1186/1471-2229-12-131.

Lewinsohn, E., Gijzen, M., 2009. Phytochemical diversity: the sounds of silent metabolism. Plant Science 176, 161-169, doi: 10.1016/j.plantsci.2008.09.018.

Li, X., Schuler, M.A., Berenbaum, M.R., 2007. Molecular mechanisms of metabolic resistance to synthetic and natural xenobiotics. Annu.al Review of Entomology 52, 231253.

Lichtenthaler, H.K., 1996. Vegetation stress: an introduction to the stress concept in plants. Journal of Plant Physiology 148, 4-14, doi:10.1016/S0176-1617(96)80287-2. 
Liess, M., Beketov, M., 2011. Traits and stress: keys to identify community effects of low levels of toxicants in test systems. Ecotoxicology 20, 1328-1340, doi:10.1007/s10646011-0689-y.

Lindblom, T.H., Dodd, A.K., 2006. Xenobiotic detoxification in the nematode Caenorhabditis elegans. Journal of Experimental Zoology A 305, 720-729, doi: 10.1002/jez.a.324.

Loeschcke, V., Sorensen, J.G., Kristensen, T.N., 2004. Ecologically relevant stress resistance: from microarrays and quantitative trait loci to candidate genes - A research plan and preliminary results using Drosophila as a model organism and climatic and genetic stress as model stresses. Journal of Biosciences 29, 503-511, doi:10.1007/BF02712122.

Londo, J.P., McKinney, J., Schwartz, M., Bollman, M., Sagers, C., Watrud, L., 2014. Sublethal glyphosate exposure alters flowering phenology and causes transient malesterility in Brassica spp. BMC Plant Biology 14, 70-79, doi:10.1186/1471-2229-14-70.

Lunn, J.E., Delorge I., Figueroa, C.M., Van Dijck, P., Stitt, M., 2014. Trehalose metabolism in plants. Plant Journal, doi: 10.1111/tpj.12509.

Lütz, C., 2010. Cell physiology of plants growing in cold environments. Protoplasma 244, 5373, doi:10.1007/s00709-010-0161-5.

MacKnight, U.S., Rasmussen, J.J., Kronvang, B., Bjerg, P.L., Binning, P.J., 2012. Integrated assessment of the impact of chemical stressors on surface water ecosystems. Science of the Total Environment 427-428, 319-331, doi: 10.1016/j.scitotenv.2012.04.011.

MacLennan, M.M., Arnott, S.E., Strecker, A.L., .2012. Differential sensitivity of planktonic trophic levels to extreme summer temperatures in boreal lakes. Hydrobiologia 680, 1123, doi:10.1007/s10750-011-0896-9.

Maestre, F.T., Bowker, M.A., Ecolar, C., Puche, M.D., Soliveres, S., Maltez-Mouro, S., Garcia-Palacios, P., Castillo-Monroy, A.P., Martinez, I., Escudero, A., 2010. Do biotic 
interactions modulate ecosystem functioning along stress gradients? Insights from semiarid plant and biological soil crust communities. Philosophical Transactions of the Royal Society B 365, 2057-2070, doi: 10.1098/rstb.2010.0016.

Manuel, N., Cornic, G., Aubert, S. et al., 1999. Protection against photoinhibition in the alpine plant Geum montanum. Oecologia 119, 149-158.

Martin, B.T., Jager, T., Nisbet, R.M., Preuss, T.G., Hammers-Wirtz, M., Grimm, V., 2013. Extrapolating ecotoxicological effects from individuals to populations: a generic approach based on Dynamic Energy Budget theory and individual-based modeling. Ecotoxicology 22, 574-583, doi: 10.1007/s10646-013-1049-x.

Medina, M.H., Correa, J.A., Barata, C., 2007. Micro-evolution due to pollution: Possible consequences for ecosystem responses to toxic stress. Chemosphere 67, 2105-2114, doi:10.1016/j.chemosphere.2006.12.024.

Menge, B.A., Sutherland, J.P., 1987. Community regulation: variance in disturbance, competition, and predation in relation to environmental stress and recruitment. The American Naturalist 130, 730-757.

Michaud, M.R., Benoit, J.B., Lopez-Martinez, G., Elnitsky, M.A., Lee, R.E., Denlinger, D.L., 2008. Metabolomics reveals unique and shared metabolic changes in response to heat shock, freezing and desiccation in the Antarctic midge, Belgica antarctica. Journal of Insect Physiology 54, 645-655, doi: 10.1016/j.jinsphys.2008.01.003.

Moe, S.J., De Schamphelaere, K., Clements, W.H., Sorensen, M.T., Van den Brink, P.J., Liess, M., 2013. Combined and interactive effects of global climate change and toxicants on populations and communities. Environmental Toxicology and Chemistry 32, 49-61, doi:10.1002/etc.2045. 
Moller, I.M., Jensen, P.E., Hansson, A., 2007. Oxidative modifications to cellular components in plants. Annual Review of Plant Biology 58, 459-481, doi:10.1146/annurev.arplant.58.032806.103946.

Morita-Yamamuro, C., Tsutsui, T., Sato,M., Yoshioka,H., Tamaoki,M., Ogawa, D., Matsuura, H., Yoshihara, T., Ikeda,A., Uyeda, I., Yamaguchi, J., 2005. The Arabidopsis Gene CAD1 Controls Programmed Cell Death in the Plant Immune System and Encodes a Protein Containing a MACPF Domain. Plant Cell Physiology 46, 902-912, doi: 10.1093/pcp/pci095.

Mouthon, J., Daufresne, M., 2006. Effects of the 2003 heatwave and climatic warming on mollusc communities of the Saône: a large lowland river and of its two main tributaries (France). Global Change Biology 12, 441-449, doi:10.1111/j.1365-2486.2006.01095.x.

Muturi, E.J., Lampman, R., Costanzo, K., Alto, B.W., 2011. Effect of temperature and insecticide stress on life-history traits of Culex restuans and Aedes albopictus (Diptera: Culicidae). Journal of Medical Entomology 48, 243-250.

Nilsson-Örtman, V., Stoks, R., De Block, M., Johansson, F., 2012. Generalists and specialists along a latitudinal transect: patterns of thermal adaptation in six species of damselflies. Ecology 93, 1340-1352.

Ober, D., 2005. Seeing double: gene duplication and diversification in plant secondary metabolism. Trends Plant Science 10, 444-449.

Oberst, A., Bender, C., Green, D.R., 2008. Living with death: the evolution of the mitochondrial pathway of apoptosis in animals. Cell Death \& Differentiation 15, 11391146, doi: $10.1038 /$ cdd.2008.65.

Odum, E.P., 1985. Trends Expected in Stressed Ecosystems. BioScience 35, 419-422, doi: $10.2307 / 1310021$. 
Oehlmann, J., Oetken, M., Schulte-Oehlmann, U., 2008. A critical evaluation of the environmental risk assessment for plasticizers in the freshwater environment in Europe, with special emphasis on bisphenol A and endocrine disruption. Environmental Research 108, 140-149.

Owen, J., Hedley, B.A., Svendsen, C., Wren, J., Jonker, M.J., Hankard, P.K., Lister, L.J., Stürzenbaum, S.R., Morgan, A.J., Spurgeon, D.J. et al., 2008. Transcriptome profiling of developmental and xenobiotic responses in a keystone soil animal, the oligochaete annelid Lumbricus rubellus. BMC Genomics 9, 266-286, doi:10.1186/1471-2164-9266.

Ozinga, W., Colles, A., Bartish, I., Hennion, F., Hennekens, S., Pavoine, S., Poschlod, P., Hermant, M., Schaminée, J., Prinzing, A., 2013. Specialists leave fewer descendants within a region than generalists. Global Ecology and Biogeography 22, 213-222, doi: 10.1111/j.1466-8238.2012.00792.x.

Pannard, A., Le Rouzic, B., Binet, F., 2009. Response of phytoplankton community to low dose atrazine exposure combined with phosphorus fluctuations. Archives of Environmental Contamination and Toxicology 57, 50-59, doi: 10.1007/s00244-0089245-z.

Park, R.A., Clough, J.S., Wellman, M.C., 2008. AQUATOX: Modeling environmental fate and ecological effects in aquatic ecosystems. Ecological Modelling 213, 1-15, doi:10.1016/j.ecolmodel.2008.01.015.

Peñuelas, J., Sardans, J., Estiarte, M., Àogaya, R., Carnicer, J., Coll, M., Barbeta, A., RivaUbach, A., Llusià, J., Garbulsky, M., Filella, I., Jump, A.S., 2013. Evidence of current impact of climate change on life: a walk from genes to the biosphere. Global Change Biology 19, 2303-2338, doi: 10.1111/gcb.12143. 
Pierce, S., Vianelli, A., Cerabolini, B., 2005. From ancient genes to modern communities: the cellular stress response and the evolution of plant strategies. Functional Ecology 19, 763-776, doi:10.1111/j.1365-2435.2005.01028.x.

Pip, E., 2000. The decline of freshwater molluscs in southern Manitoba. The Canadian FieldNaturalist 14, 555-560.

Raff, M.C., 1992. Social control on cell survival and cell death. Nature 356, 397-399.

Ramel, F., Sulmon, C., Cabello-Hurtado, F., Taconnat, L., Martin-Magniette, M.L., Renou, J.P., El Amrani, A., Couée, I., Gouesbet, G., 2007. Genome-wide interacting effects of sucrose and herbicide-mediated stress in Arabidopsis thaliana: novel insights into atrazine toxicity and sucrose-induced tolerance. BMC Genomics 5, 8-450, doi:10.1186/1471-2164-8-450.

Ramel, F., Sulmon, C., Bogard, M., Couée, I., Gouesbet, G., 2009a. Differential patterns of reactive oxygen species and antioxidative mechanisms during atrazine injury and sucrose-induced tolerance in Arabidopsis thaliana plantlets. BMC Plant Biology 13, 928, doi:10.1186/1471-2229-9-28.

Ramel, F., Sulmon, C., Gouesbet, G., Couée, I., 2009b. Natural variation reveals relationships between pre-stress carbohydrate nutritional status and subsequent responses to xenobiotic and oxidative stress in Arabidopsis thaliana. Annals of Botany 104, $1323-$ 37, doi:10.1093/aob/mcp243.

Rea, P.A., Li, Z.S., Lu, Y.P., Drozdowicz, Y.M., Martinoia, E.,1998. From vacuolar GS-X pumps to multispecific ABC transporters. Annual Review of Plant Physiology and Plant Molecular Biology 49, 727-760.

Relina, L.I., Gulevsky, A.K., 2003. A possible role of molecular chaperones in cold adaptation. CryoLetters 24, 203-212. 
Relyea R., Hoverman, J., 2006. Assessing the ecology in ecotoxicology: a review and synthesis in freshwater systems. Ecology Letters 9, 1157-1171, doi: 10.1111/j.14610248.2006.00966.x.

Renault, D., Bouchereau, A., Delettre, Y.R., Hervant, F., Vernon, P., 2006. Changes in free amino acids in Alphitobius diaperinus (Coleoptera: Tenebrionidae) during thermal and food stress. Comparative Biochemistry and Physiology A 143, 279-285, doi:10.1016/j.cbpa.2005.11.012.

Renault, D., 2011. Long-term after effects of cold-exposure in adult Alphitobius diaperinus (Tenebrionidae): the need to link survival ability with subsequent reproductive success. Ecological Entomology 36, 36-42, doi:10.1111/j.1365-2311.2010.01243.x.

Rhee, H.J., Kim, E.J., Lee, J.K., 2007. Physiological polyamines: simple primordial stress molecules. Journal of Cellular and Molecular Medicine 11, 685-703, doi:10.1111/j.1582-4934.2007.00077.x.

Riaz, M.A., Poupardin, R., Reynaud, S., Strode, C., Ranson, H., David, J.P., 2009. Impact of glyphosate and benzo[a]pyrene on the tolerance of mosquito larvae to chemical insecticides. Role of detoxification genes in response to xenobiotics. Aquatic Toxicology 93, 61-69, doi:10.1016/j.aquatox.2009.03.005.

Richmond, C.E., Breitburg, D.L., Rose, K.A., 2005. The role of environmental generalist species in ecosystem function. Ecological Modelling 188, 279-295, doi:10.1016/j.ecolmodel.2005.03.002.

Roelofs, D., Aarts, M.G.M., Schat, H., van Straalen, N.M., 2008. Functional ecological genomics to demonstrate general and specific responses to abiotic stress. Functional Ecology 22, 8-18, doi:10.1111/j.1365-2435.2007.01312.x. 
Rohr, J.R., Crumrine, P.W., 2005. Effects of an herbicide and an insecticide on pond community structure and processes. Ecological Applications 15, 1135-1147, doi:10.1890/03-5353.

Roitsch, T., 1999. Source-sink regulation by sugar and stress. Current Opinion in Plant Biology 2, 198-206, doi: 10.1016/S1369-5266(99)80036-3.

Rubal, M., Veiga, P., Reis, P.A., Bertocci, I., Sousa-Pinto, I., 2014. Effects of subtle pollution at different levels of organisation on species-rich assemblages. Environmental Pollution 191, 101-110, doi: http://dx.doi.org/10.1016/j.envpol.2014.04.019.

Russell, R.J., Scott, C., Jackson, C.J., Pandey, R., Pandey, G., Taylor, M.C., Coppin, C.W., Liu, J.W., Oakeshott, J.G., 2011. The evolution of new enzyme function: lessons from xenobiotic metabolizing bacteria versus insecticide-resistant insects. Evolutionary Applications 4, 225-248, doi:10.1111/j.1752-4571.2010.00175.x.

Saladin, G., Magne, C., Clement, C., 2003. Impact of flumioxazin herbicide on growth and carbohydrate physiology in Vitis vinifera L. Plant Cell Reports 21, 821-827.

Sandel, B., Dangremond,E.M.,2012. Climate change and the invasion of California by grasses. Global Change Biology 18, 277-289, doi:10.1111/j.1365-2486.2011.02480.x.

Sandermann, H.,1992. Plant metabolism of xenobiotics.Trends in Biochemical Sciences 17, $82-84$.

Schmolke, A., Thorbek, P., Chapman, P., Grimm, V., 2010. Ecological models and pesticide risk assessment: current modeling practice. Environmental Toxicology and Chemistry 29, 1006-1012, doi:10.1002/etc.120.

Seeland, A., Albrand, J., Oehlmann, J., Müller, R., 2013. Life stage-specific effects of the fungicide pyrimethanil and temperature on the snail Physella acuta (Draparnaud, 1805) disclose the pitfalls for the aquatic risk assessment under global climate change. Environmental Pollution 174, 1-9, doi: 10.1016/j.envpol.2012.10.020. 
Serra, A.A., Nuttens, A., Larvor, V., Renault, D., Couée, I., Sulmon, C.,Gouesbet, G., 2013. Low environmentally relevant levels of bioactive xenobiotics and associated degradation products cause cryptic perturbations of metabolism and molecular stress responses in Arabidopsis thaliana. Journal of Experimental Botany 64, 2753-2766, doi: $10.1093 / \mathrm{j} x \mathrm{~b} / \mathrm{ert} 119$.

Serra, A.A., Couée, I., Renault, D., Gouesbet, G., Sulmon, C., 2015. Metabolic profiling of Lolium perenne shows functional integration of metabolic responses to diverse subtoxic conditions of chemical stress. Journal of Experimental Botany, doi: pii: eru518.

Slabas, A.R., Suzuki, I., Murata, N., Simon, W.J., Hall, J.J., 2006. Proteomic analysis of the heat shock response in Synechocystis PCC6803 and a thermally tolerant knockout strain lacking the histidine kinase 34 gene. Proteomics 6, 845-864, doi:10.1002/pmic.200500196.

Smolders, R., Bervoets, L., De Coen, W., Blust, R., 2004. Cellular energy allocation in zebra mussels exposed along a pollution gradient: linking cellular effects to higher levels of biological organization. Environmental Pollution 129, 99-112, doi:10.1016/j.envpol.2003.09.027.

Srivastava, A.K., Nath Rai, A., Neilan, B.A., 2013. Stress biology of cyanobacteria: molecular mechanisms to cellular responses. CRC Press, Taylor and Francis Group.

Steinberg, C.E.W., 2012. Stress Ecology - Environmental Stress as Ecological Driving Force and Key Player in Evolution. Berlin: Springer.

Streit, B., Peter,H.M.,1978. Long-term effects of atrazine to selected freshwater invertebrates. Archiv für Hydrobiologie 55, 62-77.

Sundermann, A., Gerhardt, M., Kappes, H., Haase, P., 2013. Stressor prioritisation in riverine ecosystems: Which environmental factors shape benthic invertebrate assemblage metrics? Ecological Indicators 27, 83-96, doi:10.1016/j.ecolind.2012.12.003. 
Taguchi, G., Ubukata, T., Nozue, H., Kobayashi, Y., Takahi, M., Yamamoto, H.et al., 2010. Malonylation is a key reaction in the metabolism of xenobiotic phenolic glucosides in Arabidopsis and tobacco. Plant Journal 63, 1031-1041, doi: 10.1111/j.1365313X.2010.04298.x.

Tang, E.P.Y., Tremblay, R., Vincent, W.F., 1997. Cyanobacterial dominance of polar freshwater ecosystems: Are high-latitude mat-formers adapted to low temperature? Journal of Phycology 33, 171-181, doi:10.1111/j.0022-3646.1997.00171.x.

Tardieu, F., 2013. Plant response to environmental conditions: assessing potential production, water demand, and negative effects of water deficit. Frontiers in Physiology 4, 17-27, doi: $10.3389 /$ fphys.2013.00017.

Teets, N.M., Peyton, J.T., Ragland, G.J., Colinet, H., Renault, D., Hahn, D.A., Denlinger, D.L., 2012. Combined transcriptomic and metabolomic approach uncovers molecular mechanisms of cold tolerance in a temperate flesh fly. Physiological Genomics 44, 764 77, doi:10.1152/physiolgenomics.00042.2012.

Teets, N.M., Denlinger, D.L., 2013. Physiological mechanisms of seasonal and rapid coldhardening in insects. Physiology and Entomology 38, 105-116, doi:10.1111/phen.12019.

Thengodkar, R.R.M., Sivakami, S., 2010. Degradation of chlorpyrifos by an alkaline phosphatase from the cyanobacterium Spirulina platensis. Biodegradation 21, 637-644, doi:10.1007/s10532-010-9331-6.

Thornton, B.J., Elthon, T.E., Cerny, R.L., Siegfried, B.D., 2010. Proteomic analysis of atrazine exposure in Drosophila melanogaster (Diptera: Drosophilidae). Chemosphere 81, 235-241, doi:10.1016/j.chemosphere.2010.06.032. 
Timperio, A.M., Egidi, M.G., Zolla, L., 2008. Proteomics applied on plant abiotic stresses: role of heat shock proteins (HSP). Journal of Proteomics 71, 391-411, doi:10.1016/j.jprot.2008.07.005.

Van Doorn, W.G., Beers,E.P., Dangl,J.L., Franklin-Tong,V.E., Gallois,P., Hara-Nishimura,I., Jones, A.M., Kawai-Yamada,M., Lam,E., Mundy, J., Mur, L.A.J., Petersen, M., Smertenko, A., Taliansky, M., Van Breusegem,F., Wolpert, T., Woltering, E., Zhivotovskyand, B., Bozhkov,P.V., 2011. Morphological classification of plant cell deaths. Cell Death \& Differentiation 18, 1241-1246, doi:10.1038/cdd.2011.36.

Van Straalen, N.M., 2003. Ecotoxicology becomes stress ecology. Environmental Science \& Technology 37, 324A-330A.

Vazquez, P., Simberloff, D., 2002. Ecological specialization and susceptibility to disturbance: conjectures and refutations. The American Naturalist 159, 606-623, doi:00030147/2002/15906-0003\$15.00.

Vila-Aiub, M.M., Neve, P., Powles S.B., 2009. Evidence for an ecological cost of enhanced herbicide metabolism in Lolium rigidum. Journal of Ecology 97, 772-780, doi:10.1111/j.1365-2745.2009.01511.x.

Vinebrooke, R.D., Cottingham, K.L., Norberg, J., Scheffer, M., Dodson, S.I., Maberly, S.C., Sommer, U., 2004. Impacts of multiple stressors on biodiversity and ecosystem functioning: the role of species co-tolerance. Oikos 104, 451-457, doi:10.1111/j.00301299.2004.13255.x.

Viougeas, M.A., Rohr, R., Chamel, A., 1995. Structural changes and permeability of ivy (Hedera helix L.) leaf cuticles in relation to leaf development and after selective chemical treatments. New Phytologist 130, 337-348. 
Voigt, W., Perner, J., Davis, A.J., Eggers, T., Schumacher, J., Bahrmann, R., Fabian, B., Heinrich, W., Kohler, G., Lichter, D., Marstaller, R., Sander, F.W., 2003. Trophic levels are differentially sensitive to climate. Ecology 84, 2444-2453, doi:10.1890/02-0266.

Williams, J.W., Jackson, S.T., Kutzbach, J.E., 2007. Projected distributions of novel and disappearing climates by 2100 AD. Proceedings of the National Academy of Sciences 104, 5738-5742, doi:10.1073/pnas.0606292104.

Wonkka, C.L., Lafon, C.W., Hutton, C.M., Joslin, A.J., 2013. A CSR classification of tree life history strategies and implications for ice storm damage. Oikos 122, 209-222, doi:10.1111/j.1600-0706.2012.20346.x.

Yachi, S., Loreau, M., 1999. Biodiversity and ecosystem productivity in a fluctuating environment: the insurance hypothesis. Proceedings of the National Academy of Sciences 96, 1463-1468, doi:10.1073/pnas.96.4.1463.

Zhao, L., Jones, W.A., 2012. Expression of heat shock protein genes in insect stress responses. Invertebrate Survival Journal 9, 93-101.

Zhuang, H.M., Wang, K.F., Miyata, T., Wu, Z.J., Wu, G. Xie, L.H., 2011. Identification and expression of caspase-1 gene under heat stress in insecticide-susceptible and -resistant Plutella xylostella (Lepidoptera: Plutellidae). Molecular Biology Reports 38, 25292539, doi:10.1007/s11033-010-0391-9.

Zinn, K.E., Tunc-Ozdemir, M., Harper, J.F., 2010. Temperature stress and plant sexual reproduction: uncovering the weakest links. Journal of Experimental Botany 61, 19591968, doi:10.1093/jxb/erq053.

Zuñiga, G.E., Alberdi, M., Corcuera, L.J., 1996. Non-structural carbohydrates in Deschampsia antarctica Desv. from South Shetland Islands, maritime Antarctic. Environmental and Experimental Botany 36, 393-398. 
Zuppini, A., Andreoli, C., Baldan, B., 2007. Heat stress: an inducer of programmed cell death in Chlorella saccharophila. Plant Cell Physiology 48, 1000-1009, doi:10.1093/pcp/pcm070. 


\section{Figure caption}

Figure 1. From molecular commonality to community divergence; cascading effects of abiotic stressors on ecosystem functioning.

The commonality of stress responses decreases with the increasing complexity of the

biological system. From the individual to the ecosystem level, stress responses result from the interactions between physiological trade-offs, evolutionary history, and additional

environmental constraints. The role of the co-tolerance and the functional diversity in stress responses are underlined, as well as the relevance of functional biomarkers (online version in color).

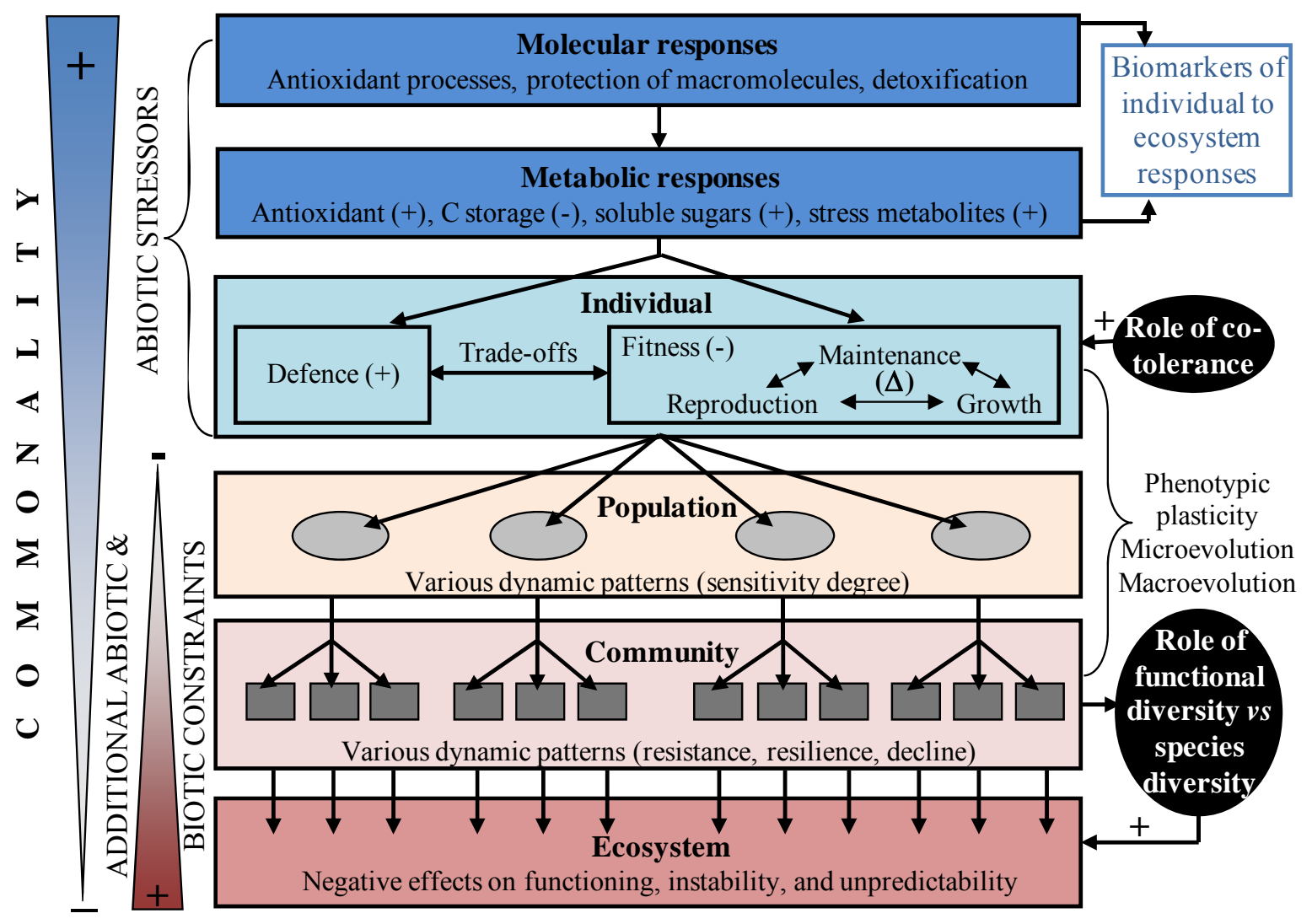

